\title{
An Exploration in the Theory of Exchange-Rate Regimes
}

\section{Citation}

Helpman, Elhanan. 1981. An exploration in the theory of exchange-rate regimes. Journal of Political Economy 89(5): 865-890.

\section{Published Version}

doi:10.1086/261011

\section{Permanent link}

http://nrs.harvard.edu/urn-3:HUL.InstRepos:3445091

\section{Terms of Use}

This article was downloaded from Harvard University's DASH repository, and is made available under the terms and conditions applicable to Other Posted Material, as set forth at http:// nrs.harvard.edu/urn-3:HUL.InstRepos:dash.current.terms-of-use\#LAA

\section{Share Your Story}

The Harvard community has made this article openly available.

Please share how this access benefits you. Submit a story.

Accessibility 


\title{
CHICAGO JOURNALS
}

\author{
An Exploration in the Theory of Exchange-Rate Regimes \\ Author(s): Elhanan Helpman \\ Source: The Tournal of Political Economy, Vol. 89, No. 5 (Oct., 1981), pp. 865-890 \\ Published by: The University of Chicago Press \\ Stable URL: http://www.jstor.org/stable/1830811
}

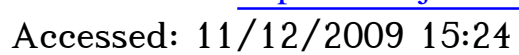

Your use of the JSTOR archive indicates your acceptance of JSTOR's Terms and Conditions of Use, available at http://www.jstor.org/page/info/about/policies/terms.jsp. JSTOR's Terms and Conditions of Use provides, in part, that unless you have obtained prior permission, you may not download an entire issue of a journal or multiple copies of articles, and you may use content in the JSTOR archive only for your personal, non-commercial use.

Please contact the publisher regarding any further use of this work. Publisher contact information may be obtained at http://www.jstor.org/action/showPublisher?publisherCode=ucpress.

Each copy of any part of a JSTOR transmission must contain the same copyright notice that appears on the screen or printed page of such transmission.

JSTOR is a not-for-profit service that helps scholars, researchers, and students discover, use, and build upon a wide range of content in a trusted digital archive. We use information technology and tools to increase productivity and facilitate new forms of scholarship. For more information about JSTOR, please contact support@jstor.org.

The University of Chicago Press is collaborating with JSTOR to digitize, preserve and extend access to The Journal of Political Economy. 


\section{An Exploration in the Theory of Exchange-Rate Regimes}

\section{Elhanan Helpman}

Tel-Aviv University

Three exchange-rate regimes-a float, a one-sided peg, and a cooperative peg-are evaluated and compared in terms of efficiency and welfare levels. The framework of analysis embodies countryspecific monies, with the money of each country being used to transact in its commodity markets and its currency-denominated bonds. Welfare levels depend only on consumption levels. In the presence of perfect foresight all equilibrium allocations are Pareto efficient. In a floating exchange-rate regime the perfect foresight equilibrium allocation coincides with an equilibrium of a costless barter economy. The same result holds in a one-sided peg if the pegging country's exchange-rate stabilizing authority breaks even over time. In a cooperative peg regime there is a different equilibrium allocation for each combination of exchange-rate levels and monetary policies. Problems of policy coordination and conflicts in desired monetary policies are discussed.

\section{Introduction and Summary}

The literature on international economics lacks systematic comparisons of welfare levels that are attained in different exchange-rate

This paper is based upon work supported by the National Science Foundation under grant no. SOC 78-06696 and the Foerder Institute for Economic Research. The main part of the study was performed when I was on leave at the University of Rochester. An earlier version of the paper was presented at seminars at the University of Rochester, the University of Western Ontario, the Institute for International Economic Studies at the University of Stockholm, and the University of Chicago. I wish to thank Robert Barro, Jacob Frenkel, Assaf Razin, and a referee for helpful comments. 
systems. Nevertheless, this type of information is essential for a wellfounded opinion about the relative desirability of alternative exchange-rate regimes, like fixed as opposed to floating. The need for research in this area can hardly be overemphasized, and it is more surprising that only very recently have there been attempts to provide such comparisons.

It is clear that in any analysis of exchange-rate systems the specification of the role of money will play a major role because, after all, an exchange rate is a relative price of two monies. It is, however, unsatisfactory to model money as an asset which serves only as a store of value, as is frequently done, because in this case money is just another asset without intrinsic features. An explicit modeling of these roles is required for a proper evaluation of the relative desirability of alternative exchange-rate regimes.

The present investigation is based on a specification of the role of money. Money can be used as a store of value, but it also has to be used in every market transaction. Purchases of commodities require payments in money, lending requires money to be transferred from the lender to the borrower, and debt repayments require money to be transferred from the debtor to the creditor. This is, of course, an application of the constraint transactions approach to the demand for money that was suggested by Clower (1967) (for a recent application see Lucas $[1980 a])$. Most important, since I deal with more than one country-each country having its own money-it is assumed that for purchases of a particular country's goods one has to pay with that country's money. (This specification is also adopted by Stockman [1980], Helpman and Razin [1980], and Lucas [1980b].) Moreover, particular currency-denominated loans are given by providing the borrower with this currency. Debt repayments are done with the currency in which the debt is denominated. This specification of the transactions role of money introduces natural liquidity constraints into the economic system, and it clearly distinguishes money from other financial assets.

My framework of analysis, which incorporates money in the above-described way into an intertemporal model in which utility levels depend only on consumption levels, is presented in Section II. In the remainder of the paper the model is used to investigate three types of exchange-rate regimes: a floating exchange-rate regime and two types of fixed exchange-rate regimes. I discuss the implications of these regimes about global efficiency and about the distribution of welfare, as well as the determination of financial variables like prices, exchange rates, and interest rates. The emphasis is on financial aspects of exchange-rate regimes.

The fixed exchange-rate regimes that are considered are a onesided peg and a cooperative peg. The one-sided peg is a regime in 
which one country pegs its exchange rate vis-à-vis another currency, and the foreign exchange authority of the pegging country engages in foreign borrowing (lending) in order to finance its foreign exchange operations. The foreign exchange authority is constrained to repay its debts. In the cooperative regime there is a foreign exchange authority which is supported by all countries. This means that whenever it needs to sell a currency of a particular type, the country whose currency is required will provide the currency to the foreign exchange authority. There are important differences in the implications of these systems. At this stage I wish only to point out that, in the former, balance-of-payments adjustments do not change the quantity of money in circulation of the passive country but may change the quantity of money in circulation of the pegging country. This means that the value of money in circulation in the world economy may change as a result of balance-of-payments adjustments. In the latter system the aggregate value of money supply does not change as a result of balance-of-payments adjustments, which make it fall in line with recent modelings of the process of international adjustment under a fixed exchange rate (see, e.g., Mundell 1968, chap. 18).

Following the description of the framework of analysis, I discuss in Section III some general properties of equilibria. Most notably, it is shown that in the presence of perfect foresight the equilibrium allocation of consumption is Pareto efficient in every exchange-rate regime. The assumption of perfect foresight is extremely important for this result. It requires that governments specify their policies in advance and do not change them. For example, surprising monetary changes may destroy the efficiency of the resulting equilibrium. Although perfect foresight implies efficiency, the distribution of welfare depends on the exchange-rate system.

Section IV is devoted to a discussion of a floating exchange-rate regime. It is shown that in the presence of perfect foresight, and independently of monetary policies, the equilibrium allocation of consumption coincides with an equilibrium of a costless barter economy. Monetary policies which are specified in advance do not affect equilibrium consumption levels. It is clear from this result that in an equilibrium the liquidity constraints do not impose special constraints on the allocation of real resources. They do, however, help to determine nominal variables-prices, exchange rates, and interest rates-as is explained in that section.

The one-sided peg regime is discussed in Section V. It is shown that, provided the foreign exchange authority breaks even, in this regime too the resulting perfect foresight equilibrium allocation of consumption coincides with an equilibrium of a costless barter economy. Hence, a floating exchange-rate system and a one-sided peg have the same efficiency and distributional implications. There are, 
however, also important differences. In particular, in the one-sided peg regime there is only one exchange-rate level which enables the foreign exchange authority to break even in the face of a given policy of monetary transfers (taxes). Hence, there is need for coordination of the exchange-rate level with the required accompanying monetary-fiscal policy mix. Coordination of policies is not required in a floating exchange-rate regime.

Section VI discusses the cooperative fixed exchange-rate regime. In this regime there is no need for policy coordination. But the perfect foresight equilibrium allocation of consumption and the distribution of welfare levels depend on the exchange-rate level and the monetary-fiscal policy mix that each country adopts. Only for very particular policy specifications will the cooperative peg equilibrium allocation of consumption coincide with the equilibrium allocation of consumption in a barter economy.

There are several interesting directions in which the present study can be extended in order to shed more light on the relative desirability of alternative exchange-rate regimes. Some of them are discussed in Section VII.

\section{The Framework of Analysis}

The world that I consider consists of two countries, a home $(H)$ country and a foreign $(F)$ country. Every country produces a single output, and the two outputs are perfect substitutes in consumption. In every period a country faces a given unalterable level of output. Time is discretely measured by time periods.

Neither the assumption of a single output nor the assumption of perfect substitutability in consumption is restrictive for the purpose of this paper; the main results do not depend on these assumptions. However, the assumption that output levels are unalterable does not enable me to discuss employment problems which are of major concern in discussions of exchange-rate systems (see, e.g., Friedman 1953; Flanders and Helpman 1978).

Every country has its own money. Purchases of the home country's goods are paid for with the home country's money; purchases of the foreign country's goods are paid for with the foreign country's money. Firms sell goods and transfer the profits to their stockholders. Home country firms are owned by home country residents while foreign country firms are owned by foreign country residents. Assuming that there are no costs of production, the value of a country's output in terms of its own money is transferred by firms to its residents. ${ }^{1}$

\footnotetext{
${ }^{1}$ Since I will not deal with uncertainty elements and I will assume the existence of
} 
The precise specification of money flows is important. Money is needed for transacting in the market, and it imposes liquidity constraints on economic agents. One cannot buy goods unless one has the money to pay for them, and firms cannot distribute dividends unless they have the money to do so; all payments are done in the form of money. It is assumed, therefore, that firms distribute dividends at the end of each period. During a single period a firm accumulates money from sales of its goods, and it distributes this money to its owners at the end of the period.

An individual arrives at the beginning of period $t$ with money balances that he left in his possession in period $t-1$ (these may be home country as well as foreign country money balances) and with money balances that he has received from firms via dividend payments. At the beginning of period $t$ he has to repay his short-term debts (debts may be positive or negative) that were acquired in period $t-1$, including interest payments; these may be debts denominated in the home or foreign country's currency.

The individual can freely exchange home currency for foreign currency and vice versa. In a fixed exchange-rate regime this is done with the Exchange Rate Stabilizing Authority (ERSA for short), while in a floating exchange-rate regime this is done in the foreign exchange market. The individual can also borrow (lend) home or foreign country money at the beginning of period $t$. The completion of these transactions leaves him with certain quantities of home and foreign money as well as home and foreign currency-denominated debts (some of these may, of course, be zero). Now, part or all of the money balances can be spent on goods during period $t$-home currency on home goods and foreign currency on foreign goods-while the remaining part can be kept in order to increase next period's purchasing power. Thus, part of the total money holdings can be "money to spend" and part of it can be "money to hold" (see Hicks 1967).

In this paper I consider the case in which there are no restrictions on borrowing and lending behavior, except that debts have to be repaid. Foreign country decision variables are denoted by an asterisk, while home country decision variables are denoted without an asterisk. The world economy faces a horizon of length $T$ - the same for both countries. ${ }^{2}$

bonds, there is no need to allow trade in ownership shares in firms, because such trade adds no new real trading opportunities.

${ }^{2}$ I assume a finite horizon. It is, however, easy to see from the following analysis that the results do not change when the horizon is infinite, provided equilibria exist. In order to analyze the infinite horizon case one has to replace constraints (1f) and (2f) with the requirement that the present value of debts is nonpositive for $T$ going to infinity (see, e.g., Helpman and Razin 1981). 
The home country's representative consumer solves the following problem:

Choose

$$
\left\{c_{H t}, c_{F t}, M_{H t}, M_{F t}, B_{H t}, B_{F t}\right\}_{t=1}^{T}
$$

to maximize

$$
u_{H}\left(c_{H 1}+c_{F 1}, c_{H 2}+c_{F 2}, \ldots, c_{H T}+c_{F T}\right)
$$

subject to

$$
\begin{gathered}
c_{H t}, c_{F t}, M_{H t}, M_{F t} \geqslant 0, \quad t=1,2, \ldots, T \\
M_{H 1}+e_{1} M_{F 1} \leqslant M_{H}+B_{H 1}+e_{1} B_{F 1}+X_{H 1}, \\
p_{H t} c_{H t} \leqslant M_{H t}, \quad t=1,2, \ldots, T \\
p_{F t} c_{F t} \leqslant M_{F t}, \quad t=1,2, \ldots, T, \\
M_{H t}+e_{t} M_{F t} \leqslant\left(M_{H t-1}-p_{H t-1} c_{H t-1}\right)+e_{t}\left(M_{F t-1}-p_{F t-1} c_{F t-1}\right) \\
+p_{H t-1} y_{H t-1}-\left(1+i_{H t-1}\right) B_{H t-1}-\left(1+i_{F t-1}\right) \\
\cdot e_{t} B_{F t-1}+B_{H t}+e_{t} B_{F t}+X_{H t}, t=2,3, \ldots, T \\
B_{H t}, B_{F t} \leqslant 0
\end{gathered}
$$

where

$u_{H}=$ home country utility function that is strictly increasing in all arguments,

$c_{H t}=$ consumption of home output in period $t$,

$c_{F t}=$ consumption of foreign output in period $t$,

$M_{H t}=$ beginning-of-period holdings of home money in period $t$, $M_{F t}=$ beginning-of-period holdings of foreign money in period $t$,

$B_{H t}=$ home currency borrowing (lending when negative) at the beginning of period $t$,

$B_{F t}=$ foreign currency borrowing (lending when negative) at the beginning of period $t$,

$M_{H}=$ the initial stock of home country money,

$X_{H t}=$ government transfers (taxes if negative) to home country residents in terms of home money at the beginning of period $t$,

$e_{t}=$ the exchange rate in period $t$, defined as the price of foreign currency in terms of the home country's currency,

$p_{H t}=$ the price of home output in terms of home currency in period $t$,

$p_{F t}=$ the price of foreign output in terms of foreign currency in period $t$,

$y_{H t}=$ home output in period $t$, 
$i_{H t}=$ the nominal one-period interest rate on period $t$ home currency-denominated debt, and

$i_{F t}=$ the nominal one-period interest rate on period $t$ foreign currency-denominated debt.

At the beginning of the first period, home country residents have $M_{H}$ units of home currency, and they receive a transfer of $X_{H 1}$ units of home currency from their government. They borrow $B_{H 1}$ units of home money and $B_{F 1}$ units of foreign money. Then, they reallocate total money holdings between home and foreign currency via the foreign exchange market in a floating exchange-rate regime or the ERSA in a fixed exchange-rate regime. This way they end up holding $M_{H 1}$ units of home money and $M_{F 1}$ units of foreign money. No further financial transactions are needed during the first period. Consumers spend part or all of their money holdings on goods during the period. Thus, total beginning-of-period home money holdings are composed of $p_{H 1} c_{H 1}$ units of money to spend and $M_{H 1}-p_{H 1} c_{H 1}$ units of money to hold. This is true for foreign money holdings as well.

At the beginning of the second period, home consumers have $M_{H 1}$ $-p_{H 1} c_{H 1}$ units of home currency and $M_{F 1}-p_{F 1} c_{F 1}$ units of foreign currency. They receive dividend payments which consist of $p_{H_{1} y_{H 1}}$ units of home currency and government transfers which consist of $X_{H 2}$ units of home currency. They repay their first-period debts, including interest payments- $\left(1+i_{H_{1}}\right) B_{H_{1}}$ in home currency and $(1+$ $\left.i_{F 1}\right) B_{F 1}$ in foreign currency-and acquire new debts- $B_{H 2}$ in home currency and $B_{F 2}$ in foreign currency. They can make instantaneous transactions in the foreign exchange market or with the ERSA in order to coordinate the momentary money flows. Finally, they reallocate total money holdings between home and foreign money $-M_{H 2}$ and $M_{F 2}$. And the process continues.

We may now turn to the decision problem of the foreign country's representative consumer. His decision variables are denoted by an asterisk, the initial stock of foreign money is denoted by $M_{F}$, foreign output in period $t$ is denoted by $y_{F t}$, and government transfers (taxes if negative) to foreign residents in terms of foreign money at the beginning of period $t$ are denoted by $X_{F t}$. All other variables are as defined above (except for the asterisk).

Choose

$$
\left\{c_{H t}^{*}, c_{F t}^{*}, M_{H}^{*}, M_{F t}^{*}, B_{H}^{*}, B_{F t}^{*}\right\}_{t=1}^{T}
$$

to maximize

$$
u_{F}\left(c_{H 1}^{*}+c_{F 1}^{*}, c_{H 2}^{*}+c_{F 2}^{*}, \ldots, c_{H T}^{*}+c_{F T}^{*}\right),
$$


subject to

$$
\begin{aligned}
& c_{H t}^{*}, c_{F t}^{*}, M_{H t}^{*}, M_{F t}^{*} \geqslant 0, \quad t=1,2, \ldots, T, \\
& \frac{M_{H 1}^{*}}{e_{1}}+M_{F 1}^{*} \leqslant M_{F}+\frac{B_{H 1}^{*}}{e_{1}}+B_{F 1}^{*}+X_{F 1}, \\
& p_{H t} c_{H t}^{*} \leqslant M_{H t}^{*}, \quad t=1,2, \ldots, T, \\
& p_{F t} c_{F t}^{*} \leqslant M_{F t}^{*}, \quad t=1,2, \ldots, T, \\
& \frac{M_{H t}^{*}}{e_{t}}+M_{F t}^{*} \leqslant \frac{\left(M_{H t-1}^{*}-p_{H t-1} c_{H t-1}^{*}\right)}{e_{t}}+\left(M_{F t-1}^{*}-p_{F t-1} c_{F t-1}^{*}\right) \\
& +p_{F t-1} y_{F t-1}-\left(1+i_{H t-1}\right) \frac{B_{H t-1}^{*}}{e_{t}}-\left(1+i_{F t-1}\right) B_{F t-1}^{*} \\
& +\frac{B_{H t}^{*}}{e_{t}}+B_{F t}^{*}+X_{F t}, t=2,3, \ldots, T, \\
& B_{H T}^{*}, B \underset{F t}{*} \leqslant 0 .
\end{aligned}
$$

This is the foreign counterpart of the home country's decision problem (1).

\section{A Fundamental Property of Equilibria}

The purpose of this section is to show that all perfect foresight equilibria, independently of the exchange-rate regime, are Pareto optimal. This is an extremely strong result because it implies that in the present framework the exchange-rate regime is irrelevant from the efficiency viewpoint; that is, there is no exchange-rate regime that is more efficient than other exchange-rate regimes. This does not mean, of course, that exchange-rate regimes are irrelevant from the viewpoint of other economic considerations. For example, it may happen that different exchange-rate regimes have different distributional implications in the sense that in some of them a particular country is better off than in others. I will address this issue in the following sections when discussing particular exchange-rate regimes. At this stage I should like only to point out that the equivalence result depends strongly on the ability of governments to pursue nondistorting absorption policies whenever they are needed in order to accompany an exchange-rate regime. I will have more to say about this in Section V.

First, independently of the exchange-rate system, in an equilibrium the interest rate and purchasing power parity conditions have to be satisfied. In order to have a solution to (1) and (2) with finite values of $B_{H t}, B_{F t}, B_{H t}^{*}, B_{F t}^{*}, t=1,2, \ldots, T-1$ (last-period debt is always zero 
due to $[\mathrm{lf}]$ and $[2 \mathrm{f}]$ ), there has to be interest rate parity in every period:

$$
\left(1+i_{H t}\right)=\left(1+i_{F t}\right) \frac{e_{t+1}}{e_{t}}, t=1,2, \ldots, T-1 .
$$

For if (3) does not hold, an investor can arbitrage between foreign and domestic debt so as to make infinite profits. One can use problems (1) and (2) to show that when $\left(1+i_{H t}\right)<\left(1+i_{F t}\right)\left(e_{t+1} / e_{t}\right)$ the solutions to these problems yield $B_{H t}, B_{H t}^{*} \rightarrow+\infty$ and $B_{F t}, B_{F t}^{*} \rightarrow-\infty$, and when $\left(1+i_{H t}\right)>\left(1+i_{F t}\right)\left(e_{t+1} / e_{t}\right)$ the solutions to these problems yield $B_{H t}$, $\mathrm{B}_{H t}^{*} \rightarrow-\infty$ and $B_{F t}, B_{F t}^{*} \rightarrow+\infty$. These asset demands are, of course, inconsistent with an equilibrium.

Second, in order to have equilibrium in commodity markets there has to be purchasing power parity in every period:

$$
p_{H t}=e_{t} p_{F t}, \quad t=1,2, \ldots, T .
$$

For if $p_{H t}>e_{t} p_{F t}$, the solutions to (1) and (2)-taking into account (3) -yield zero demand for the home country's output in period $t$, which is inconsistent with the clearing of commodity markets. Similarly, if $p_{H t}<e_{t} p_{F t}$, demand for foreign output drops to zero.

In order to prove the main result of this section, it is useful to rewrite the consumer problems so as to replace the sequence of budget constraints by a single wealth constraint. This can be done in the present context despite the existence of liquidity constraints, because $(a)$ there exist bonds, $(b)$ financial assets (including monies) are freely traded at the beginning of each period, and $(c)$ the interest parity and purchasing power parity conditions are satisfied.

First, observe that in a solution to problem (1) constraints (1b) and (le) will never be satisfied with strict inequality. For if there is a strict inequality in one of these constraints, say, in period $t$, one can increase domestic or foreign money holdings at no extra cost and use it as money to spend, thus increasing consumption in period $t$ without altering all other choice variables. This will increase the attained utility level. We can rewrite, therefore, constraints (1b) and (le) in equality form without altering the nature of the problem. Second, denoting by $m_{H t}$ and $m_{F t}$ the components of home and foreign monies to hold in period $t$,

$$
\begin{aligned}
m_{H t}=M_{H t}-p_{H t} c_{H t}, & t=1,2, \ldots, T, \\
m_{F t}=M_{F t}-p_{F t} c_{F t}, & t=1,2, \ldots, T,
\end{aligned}
$$

we can replace (1c) and (1d) with nonnegativity constraints on $m_{H t}$ and $m_{F t}$.

Combining (1b) and (le)—written in equality form-with (5), and 
applying the parity conditions (3) and (4), we get:

$$
\begin{gathered}
p_{H 1} c_{1}+m_{H 1}+e_{1} m_{F 1}=M_{H}+B_{H 1}+e_{1} B_{F 1}+X_{H 1}, \\
\left(1+i_{H t-1}\right)^{-1} p_{H t} c_{t}+\left(1+i_{H t-1}\right)^{-1}\left(m_{H t}+e_{t} m_{F t}\right)-\left(1+i_{H t-1}\right)^{-1}\left(m_{H t-1}\right. \\
\left.+e_{t} m_{F t-1}\right)=\left(1+i_{H t-1}\right)^{-1}\left(p_{H t-1} y_{H t-1}+X_{H t}\right)-B_{H t-1} \\
-e_{t-1} B_{H t-1}+\left(1+i_{H t-1}\right)^{-1}\left(B_{H t}+e_{t} B_{F t}\right), \quad t=2,3, \ldots, T
\end{gathered}
$$

where $c_{t}=c_{H t}+c_{F t}=$ aggregate consumption in period $t$.

Now define the discount factors:

$$
d_{H t}=\prod_{\tau=2}^{t}\left(1+i_{H \tau-1}\right)^{-1}, \quad t=2,3, \ldots, T, \text { and } d_{H 1}=1 .
$$

Then, by adding (7) for $t=2$ to (6), adding the result to (7) for $t=3$ multiplied by $d_{H 2}$, then adding the result to (7) for $t=4$ multiplied by $d_{H 3}$, and so on, we get (using the interest parity condition [3]) the single wealth constraint:

$$
\begin{gathered}
\sum_{t=1}^{T} d_{H t} p_{H t} c_{t}+\sum_{t=1}^{T-1} d_{H t+1}\left(i_{H t} m_{H t}+e_{t+1} i_{F t} m_{F t}\right) \\
+d_{H T}\left(m_{H T}+e_{T} m_{F T}-B_{H T}-e_{T} B_{F T}\right) \\
=M_{H}+\sum_{t=1}^{T-1} d_{H t+1} p_{H t} y_{H t}+\sum_{t=1}^{T} d_{H t} X_{H t} .
\end{gathered}
$$

On the left-hand side of (9) there are three terms. The first represents the present value of consumption. The second represents the present value of interest costs associated with holding money as a store of value, that is, associated with money to hold. The last term represents the present value of last-period money to hold minus debt. On the right-hand side of (9) there are three terms too-initial money holdings, the present value of dividends, and the present value of government transfers. The sum of the right-hand-side terms represents initial wealth. Dividends are distributed at the end of each period, which explains why the firms' proceeds in period $t$ are discounted by $d_{H t+1}$ and not by $d_{H t}$.

Now problem (1) can be reformulated as follows. Choose $c_{t}, m_{H t}, m_{F t}$ $\geqslant 0, t=1,2, \ldots, T$, and $B_{H T}, B_{F T} \leqslant 0$, so as to maximize $u_{H}\left(c_{1}, c_{2}, \ldots\right.$, $c_{T}$ ) subject to (9). Having found a solution to this problem, one can find a solution to problem (1) by choosing an arbitrary division of consumption in each period between home and foreign goods, then using (5) to solve beginning-of-period money holdings, and finally using (6) and (7) to solve home and foreign borrowing. 
Applying to problem (2) the above-outlined procedure, one can derive the foreign counterpart of (9). Due to the interest and purchasing power parity conditions, the foreign wealth constraint can be written using foreign currency prices and discount factors or home currency prices and discount factors. The foreign country's decision problem can then also be reformulated using a single wealth constraint.

The new formulations of problems (1) and (2) reveal an important characteristic of equilibrium allocations. If the interest rate on currency $j$-denominated debt is positive in period $t(j=H$ or $F)$, neither the home nor the foreign country will use currency $j$ as a store of value in period $t$ (i.e., $m_{j t}$ and $m_{j t}^{*}$ will be chosen to equal zero). If, however, the interest rate on currency $j$-denominated debt is zero in period $t$, both countries will be indifferent toward using currency $j$ as a store of value in period $t$. This means that, in an equilibrium, implicit interest costs associated with money to hold are zero in every period. ${ }^{3}$ This can be seen by observing that in the reformulated problems the "price" of home money to hold is $d_{H t+1} i_{H t}$ and the "price" of foreign money to hold is $d_{H t+1} e_{t+1} i_{F t}$, while the marginal utility of money to hold is zero. The new formulation reveals also that in an equilibrium consumers make sure that the present values of lastperiod monies to hold and debts are all zero. This means that in an equilibrium the effective constraints on the choice of consumption plans are:

$$
\begin{aligned}
& \sum_{t=1}^{T} d_{H t} p_{H t} c_{t}=M_{H}+\sum_{t=1}^{T-1} d_{H t+1} p_{H t} y_{H t}+\sum_{t=1}^{T} d_{H t} X_{H t}, \\
& \sum_{t=1}^{T} d_{F t} p_{F t} c_{t}^{*}=M_{F}+\sum_{t=1}^{T-1} d_{F t+1} p_{F t} y_{F t}+\sum_{t=1}^{T} d_{F t} X_{F t} .
\end{aligned}
$$

Thus, equilibrium consumption plans are solutions to: choose $c_{t} \geqslant 0$, $t=1,2, \ldots, T$, to maximize $u_{H}\left(c_{1}, c_{2}, \ldots, c_{T}\right)$ subject to $(10)$; and choose $c_{t}^{*} \geqslant 0, t=1,2, \ldots, T$, to maximize $u_{F}\left(c_{1}^{*}, c_{2}^{*}, \ldots, c_{T}^{*}\right)$ subject to (11). Due to the interest and purchasing power parity conditions $\left(d_{F t} p_{F t}\right) /\left(d_{F 1} p_{F 1}\right)=\left(d_{H t} p_{H t}\right) /\left(d_{H 1} p_{H 1}\right)$, for $t=1,2, \ldots, T$, implying that consumers face the same relative prices of consumption in both

${ }^{3}$ This implication is a direct consequence of the assumption that one can switch costlessly from money to bonds and vice versa. With positive transaction costs associated with purchases and sales of bonds, money is used as a store of value even when interest rates are positive (see Baumol 1952 and Tobin 1956). This suggests that additional insight might be gained by extending the present model to allow for transaction costs in financial markets. 
problems. Hence, every equilibrium allocation of consumption in which consumption demands are solutions to these problems is Pareto efficient. This proves the main result of this section.

It is important to observe at this stage that the implications of being in an equilibrium which have been discussed so far are independent of the exchange-rate system; they apply to systems of fixed and floating as well as managed exchange rates. Every exchange-rate system has associated with it specific financial market-clearing conditions (the clearing conditions for commodity markets, $c_{H t}+c_{H t}^{*}=y_{H t}$ and $c_{F t}+c_{F t}^{*}=y_{F t}$, are the same for every exchange-rate regime), which may have specific distributional implications. These implications are considered in the following sections.

\section{Floating Exchange-Rate Regime}

By a floating exchange-rate regime I refer to a regime in which no government agency intervenes in the foreign exchange market for the sake of intervention. Thus, if one was to reformulate the present model to include government purchases of goods and the government was instructed to acquire foreign exchange in order to purchase foreign goods, this would introduce intervention in the foreign exchange market but not for the sake of intervention. However, if a government agency purchases foreign exchange, keeps it for several periods, and then resells it, we refer to this action as intervention for the sake of intervention. In the presence of this type of policy the exchange-rate regime is a managed float.

Now consider the economies described in the previous section in a floating exchange-rate regime. The governments are assumed to engage in no economic activity except for the monetary transfers $X_{H t}$ and $X_{F t}$ (which may be zero). This means that each currency has only one source of money creation-government transfers-that all debt is private debt, and that all commodity demands are private demands. Under these circumstances a floating exchange-rate regime equilibrium can be defined as follows:

Definition: Prices $\left\{\tilde{p}_{H t}, \tilde{p}_{F t}\right\}_{t=1}^{T}$, exchange rates $\left\{\tilde{e}_{t}\right\}_{t=1}^{T}$, interest rates $\left\{\tilde{l}_{H t}, \tilde{l}_{F t}\right\}_{t=1}^{T-1}$, and the allocation $\left\{\tilde{c}_{H t}, \tilde{c}_{F t}, \tilde{c}_{H t}^{*}, \tilde{c}_{F t}^{*}, \tilde{M}_{H t}, \tilde{M}_{F t}, \tilde{M}_{H t}^{*}, \tilde{M}_{F t}^{*}\right.$, $\left.\tilde{B}_{H t}, \tilde{B}_{F t}, \tilde{B}_{H t}^{*}, \tilde{B}_{F t}^{*}\right\}_{t=1}^{T}$ constitute a floating exchange-rate regime equilibrium relative to $\left[u_{H}, u_{F}, M_{H}, M_{F},\left\{X_{H t}, X_{F t}, y_{H t}, y_{F t}\right\}_{t=1}^{T}\right]$, if:

a) for $p_{H t}=\tilde{p}_{H t}, p_{F t}=\tilde{p}_{F t}, e_{t}=\tilde{e}_{t}, t=1,2, \ldots, T$, and $i_{H t}=\tilde{\imath}_{H t}, i_{F t}=\tilde{\imath}_{F t}$, $t=1,2, \ldots, T-1$,

i) $\left\{\tilde{c}_{H t}, \tilde{c}_{F t}, \tilde{M}_{H t}, \tilde{M}_{F t}, \tilde{B}_{H t}, \tilde{B}_{F t}\right\}_{t=1}^{T} \quad$ solves (1),

ii) $\left\{\tilde{c}_{H t}^{*}, \tilde{c}_{F t}^{*}, \tilde{M}_{H t}^{*}, \tilde{M}_{F t}^{*}, \tilde{B}_{H t}^{*}, \tilde{B}_{F t}^{*}\right\}_{t=1}^{T} \quad$ solves (2),

b) $\tilde{c}_{H t}+\tilde{c}_{H t}^{*}=y_{H t}, t=1,2, \ldots, T$, 
c) $\tilde{c}_{F t}+\tilde{c}_{F t}^{*}=y_{F t}, t=1,2, \ldots, T$,

d) $\tilde{M}_{H t}+\tilde{M}_{H t}^{*}=M_{H}+\sum_{\tau=1}^{t} X_{H \tau}, t=1,2, \ldots, T$,

e) $\tilde{M}_{F t}+\tilde{M}_{F t}^{*}=M_{F}+\sum_{\tau=1}^{t} X_{F \tau}, t=1,2, \ldots, T$,

f) $\tilde{B}_{H t}+\tilde{B}_{H t}^{*}=0, t=1,2, \ldots, T$,

g) $\tilde{B}_{F t}+\tilde{B}_{F t}^{*}=0, t=1,2, \ldots, T$.

In an equilibrium, individual optimization based on self-fulfilling expectation (condition $a$ ) is consistent with clearance of all markets in every period; market for home output (condition $b$ ), market for foreign output (condition $c$ ), market for home money (condition $d$ ), market for foreign money (condition $e$ ), market for home currencydenominated debt (condition $f$ ), and market for foreign currencydenominated debt (condition $g$ ).

The right-hand side of condition $d$ represents the supply of home money in period $t$; it consists of the initial stock of money plus monetary injections up to (and including) period $t$. Similarly, the right-hand side of condition $e$ represents the supply of foreign money to the private sector in period $t$.

The main point that $I$ wish to make in this section is thatindependent of the transfer policies $\left(X_{H t}\right.$ and $\left.X_{F t}\right)$-in a floating exchange-rate regime the equilibrium allocation of consumption conforms to a barter equilibrium allocation of the economies under consideration, and vice versa. That is, if we allow the economies to exchange goods over time, making all trading decisions in the beginning of the first period (as in an Arrow-Debreu model), the resulting equilibrium allocation of consumption will be an equilibrium allocation of consumption in a floating exchange-rate regime, and vice versa. This is independent of the transfer policies (or, as some would call it, of monetary policies).

Despite the fact that the equilibrium allocation of consumption is determined only by real factors (the factors which determine an exchange equilibrium), every real equilibrium has associated with it equilibrium values of monetary variables like commodity prices, exchange rates, and interest rates (cf. Kareken and Wallace, in press). The monetary variables are determined within the system.

In order to prove the main result of this section recall the formulation of the optimal consumption plan problems that was developed at the end of Section III.

Choose

$$
c_{t} \geqslant 0, \quad t=1,2, \ldots, T
$$


to maximize

$$
u_{H}\left(c_{1}, c_{2}, \ldots, c_{T}\right)
$$

subject to

$$
\sum_{t=1}^{T} d_{H t} p_{H t} c_{t}=M_{H}+\sum_{t=1}^{T-1} d_{H t+1} p_{H t} y_{H t}+\sum_{t=1}^{T} d_{H t} X_{H t}
$$

Choose

$$
c_{t}^{*} \geqslant 0, \quad t=1,2, \ldots, T,
$$

to maximize

$$
u_{F}\left(c_{1}^{*}, c_{2}^{*}, \ldots, c_{T}^{*}\right)
$$

subject to

$$
\sum_{t=1}^{T} d_{F t} p_{F t} c_{t}^{*}=M_{F}+\sum_{t=1}^{T-1} d_{F t+1} p_{F t} y_{F t}+\sum_{t=1}^{T} d_{F t} X_{F t}
$$

Equilibrium consumption schedules are solutions to these problems independent of the exchange-rate regime.

It is shown in the Appendix that, in a floating exchange-rate regime equilibrium, the right-hand side of the wealth constraint in (12) is equal to $\Sigma_{t=1}^{T} d_{H t} p_{H t} y_{H t}$ while the right-hand side of the wealth constraint in (13) is equal to $\Sigma_{t=1}^{T} d_{F t} p_{F t} y_{F t}$. This means that in each country the present value of output equals the value of initial money holdings plus the present value of dividends plus the present value of government transfers. Hence, a country's assets reflect precisely the value of its real output. Now, since $\left(d_{F t} p_{F t}\right) /\left(d_{F 1} p_{F 1}\right)=\left(d_{H t} p_{H t}\right) /\left(d_{H 1} p_{H 1}\right)$ (due to interest rate and purchasing power parity), an equilibrium allocation of consumption in a floating exchange-rate regime-which is a solution of (12) and (13)-coincides with an equilibrium allocation of consumption in a costless barter economy. ${ }^{4}$ Hence, despite the fact that the monies play a real role in facilitating transactions, thus introducing potential divergences from barter equilibria, in a floating exchange-rate regime with perfect foresight no such divergences exist.

The fact that the equilibrium allocation of consumption in a floating exchange-rate regime coincides with the equilibrium allocation of consumption in a costless barter regime enables a rather simple calculation of equilibrium prices, exchange rates, and nominal interest rates. First, compute the equilibrium relative intertemporal prices in the barter regime. Let them be $q_{1}=1, q_{2}, q_{3}, \ldots, q_{T}$. Then we know

4 This result is also derived in Lucas (1980b). 
that in the floating exchange-rate regime prices and interest rates satisfy:

$$
\frac{d_{H t} p_{H t}}{d_{H t-1} p_{H t-1}}=\frac{d_{F t} p_{F t}}{d_{F t-1} p_{F t-1}}=\frac{q_{t}}{q_{t-1}}, \quad t=2,3, \ldots, T .
$$

Now, in the last period all money is spent on goods. Therefore, last-period prices are

$$
p_{H T}=\frac{\left(M_{H}+\sum_{\tau=1}^{T} X_{H \tau}\right)}{y_{H T}}, p_{F T}=\frac{\left(M_{F}+\sum_{\tau=1}^{T} X_{F \tau}\right)}{y_{F T}} .
$$

Having last-period prices, we can determine prices and interest rates in period $T-1$. From (14), using $d_{k t} / d_{k t-1}=\left(1+i_{k t-1}\right)^{-1}, k=H, F$, we have

$$
\left(1+i_{H T-1}\right) p_{H T-1}=\frac{p_{H T} q_{T-1}}{q_{T}},\left(1+i_{F T-1}\right) p_{F T-1}=\frac{p_{F T} q_{T-1}}{q_{T}} .
$$

First consider $p_{H T-1}$ and $i_{H T-1}$. Suppose $i_{H T-1}>0$. Then all $H$ money is spent on $H$ goods in period $T-1$ and

$$
p_{H T-1}=\frac{\left(M_{H}+\sum_{\tau=1}^{T-1} X_{H \tau}\right)}{y_{H T-1}} .
$$

Substituting this into (15), we calculate the interest rate $i_{H T-1}$ which satisfies (15). If the calculated interest rate is nonnegative, we have the equilibrium price level and interest rate. If the calculated interest rate is negative, then the equilibrium interest rate is zero. Substituting $i_{H T-1}$ $=0$ into (15), we can calculate the equilibrium price $p_{H T-1}$. A similar procedure is applied to calculate $i_{F T-1}$ and $P_{F T-1}$. It is now clear that we can use the same procedure to calculate $p_{H T-2}, i_{H T-2}, p_{F T-2}$, and $i_{H T-2}$. Thus, starting from last-period prices, all prices and interest rates can be recursively calculated.

Observe that prices are determined according to the quantity theory of money. When a country's money is not used as a store of value, all of it "chases" that country's goods, and the country's price level is determined according to the quantity equation with unitary velocity of circulation. When part of the money is used as a store of value, which may happen in this model only if the nominal interest rate is zero in this country, only part of the stock of money in circulation chases goods, and this part determines the price level. In fact, if the algorithm described above produces a zero interest rate in a certain period, the calculated price level of this period can be used in conjunction with output to calculate the quantity of money re- 
quired for transactions. The residual quantity of money will be used as money to hold..$^{5}$

\section{Fixed Exchange-Rate Regime: One-sided Peg}

In this section I consider a fixed exchange-rate regime in which the home country pegs its exchange rate to the foreign country. For this purpose the home country establishes an exchange-rate stabilizing authority (ERSA) whose task is to buy and sell foreign currency at the fixed rate of exchange $e$, which is assumed to remain the same in every period. The ERSA replaces the foreign exchange market. Since the home country cannot issue foreign money, its one-sided decision to peg the exchange rate makes it necessary for the ERSA to borrow abroad whenever it is asked to sell foreign currency, and I assume that whenever it is asked to buy foreign currency it lends it out. This assumption avoids unnecessary interest costs to the ERSA (these interest costs are sometimes considered as part of the costs of exchange-rate stabilization). Also, it is assumed that, whenever the ERSA buys foreign currency, it pays for it with new issues of home currency, thus increasing the quantity of home money in circulation. Whenever the ERSA sells foreign currency, it leaves in its possession the home currency that it receives against these sales, thereby reducing the quantity of home money in circulation. This mechanism of exchange-rate stabilization approximates practices that were used in many countries (central banks usually perform the tasks of the ERSA).

In what follows I wish to make two main points. One concerns the distributional implications of the exchange-rate system that is being considered (we know from Sec. II that the equilibrium allocation of consumption is efficient). It will be shown that when the ERSA is constrained to end up with no foreign debt, the resulting equilibrium allocation of consumption is the same as in a costless barter economy and, therefore, also the same as in a floating exchange-rate regime. Second, in order to meet the ERSA's intertemporal budget constraint (the constraint on last period's foreign debt), the transfer policy cannot be arbitrary. This means that in the present system the transfer policy cannot be divorced from the stabilization of the exchange rate, which may be considered as a disadvantage of this fixed exchangerate regime. ${ }^{6}$ Apart from these points we will have a closer look at the

${ }^{5}$ An explicit calculation of an equilibrium for two toy economies is presented in Helpman (1979). Helpman and Razin (1981) present a similar calculation for the infinite horizon case.

${ }^{6}$ A similar argument, but in a different setup, appears in Helpman and Razin (1979). 
behavior of prices and money stocks and the relationship between the exchange rate and the required transfer or absorption policy.

I start by presenting the ERSA's budget constraint. In order to save space let us use the convention that variables with a subscript $t-1$ are all zero for $t=1$. The ERSA's foreign debt in period $t$ is denoted by $B_{F t}^{E}$ and its addition to $H$ money in circulation in period $t$ is denoted by $X_{H t}^{E}\left(X_{H t}^{E}\right.$ may, of course, be positive or negative). The exchange rate is constant; that is, $e_{t}=e$.

There are two economic units which actively transact with the ERSA: the private sector of the home country and the private sector of the foreign country. The private sector of the home country has in period $t$ an excess demand for foreign currency which equals $M_{F t}+(1$ $\left.+i_{F t-1}\right) B_{F t-1}-m_{F t-1}-B_{F t}$; it equals total desired holdings of foreign currency, plus foreign debt repayments, minus the quantity of foreign currency transferred from the previous period (the previous period's foreign money to hold), minus foreign borrowing. This excess demand is satisfied by purchases of foreign currency from the ERSA, for which the private sector pays with home country money. The foreign private sector has an excess demand for home currency which equals $M_{H t}^{*}+\left(1+i_{H t-1}\right) B_{H t-1}^{*}-m_{H t-1}^{*}-B_{H t}^{*}$. This excess demand is also satisfied by transacting with the ERSA. For the purchase of home currency the foreign private sector pays $\left[M_{H t}^{*}+\left(1+i_{H t-1}\right) B_{H t-1}^{*}\right.$ $\left.-m_{H t-1}^{*}-B_{H t}^{*}\right] / e$ units of foreign currency. Hence, the deficit in the balance of payments which equals the net excess demand for foreign currency with which the ERSA is faced in period $t$ is:

$$
\begin{aligned}
D_{F t}= & {\left[M_{F t}+\left(1+i_{F t-1}\right) B_{F t-1}-m_{F t-1}-B_{F t}\right] } \\
& -\frac{\left[M_{H t}^{*}+\left(1+i_{H t-1}\right) B_{H t-1}^{*}-m_{H t-1}^{*}-B_{H t}^{*}\right]}{e} .
\end{aligned}
$$

Against this excess demand for foreign currency there is an equal value excess supply of home currency which the ERSA has to absorb. Hence, $X_{H t}^{E}=-e D_{F t}$, and

$$
\begin{aligned}
X_{H t}^{E}= & -e\left[M_{F t}+\left(1+i_{F t-1}\right) B_{F t-1}-m_{F t-1}-B_{F t}\right] \\
& +\left[M_{H t}^{*}+\left(1+i_{H t-1}\right) B_{H t-1}^{*}-m_{H t-1}^{*}-B_{H t}^{*}\right] .
\end{aligned}
$$

Apart from the net excess demand for foreign currency by the private sector in period $t$, the ERSA needs foreign currency in order to repay the debt that it acquired in period $t-1$. Hence, the ERSA's foreign borrowing in period $t$ equals the private sector's net excess demand for foreign currency plus its repayments of foreign debt:

$$
\begin{aligned}
B_{F t}^{E}= & {\left[M_{F t}+\left(1+i_{F t-1}\right) B_{F t-1}-m_{F t-1}-B_{F t}\right] } \\
& -\frac{\left[M_{H t}^{*}+\left(1+i_{H t-1}\right) B_{H t-1}^{*}-m_{H t-1}^{*}-B_{H t}^{*}\right]}{e}+\left(1+i_{F t-1}\right) B_{F t-1}^{E} .
\end{aligned}
$$


The last equation is based on the assumption that the ERSA does not carry forward any foreign currency; when it has foreign currency it either sells it or lends it out. This assumption assures efficient management of the exchange-rate stabilizing operations. ${ }^{7}$ From (16) and (18), we have:

$$
D_{F t}=B_{F t}^{E}-B_{F t-1}^{E}-i_{F t-1} B_{F t-1}^{E} .
$$

The deficit in the balance of payments equals the increase in the ERSA's foreign debt minus its interest payments. This is the definition of the deficit in the balance of payments which associates the deficit with the ERSA's net sales of foreign currency to the private sectors, which also reflects the contraction of home currency in circulation due to the balance of payments. However, in this framework it might be more appropriate to define the deficit as the increase in the ERSA's foreign debt. The difference between the former and latter definitions amounts to the exclusion or inclusion, respectively, of interest payments on the ERSA's foreign debt in the definition of the deficit in the balance of payments. Clearly, if the latter definition is used, then the contraction in home money in circulation as a result of exchangerate stabilization is not equal to the deficit in the balance of payments.

Now we are prepared to define a one-sided peg fixed exchange-rate regime equilibrium. A formal definition is provided in Helpman (1979). Here I discuss informally the difference between the onesided peg equilibrium and the floating exchange-rate equilibrium.

In the one-sided peg the ERSA stabilizes the exchange rate at a fixed level $e$ in all periods. Hence $e_{t}=e$ for $t=1,2, \ldots, T$. As a result, it engages in foreign borrowing $\left(B_{F t}^{E}\right)$ and monetary injections $\left(X_{H t}^{E}\right)$. Since the ERSA has to satisfy its temporal budget constraints and break even over time, all choice variables-private as well as the ERSA's-have to satisfy (17) and (18). In addition, the exchange-rate stabilizing authority has to end up with no foreign debts:

$$
B_{F T}^{E^{\prime}}=0 \text {. }
$$

Of course, commodity markets have to clear, so that conditions $b$ and $c$ from the definition of a floating exchange-rate equilibrium apply also to the present regime. Finally, money markets and bond markets have to clear. Since our ERSA does not operate in the domestic bond market, it does not carry forward foreign money, and it does not make foreign currency transfers, conditions $e$ and $f$ from the definition of a floating exchange-rate equilibrium apply also to the present regime. A difference arises in the equilibrium conditions for the home currency market and the foreign bond market, because the

\footnotetext{
${ }^{7}$ See, however, Helpman and Razin (1980) for a case in which, due to uncertainty, the ERSA has to carry forward some foreign currency.
} 
ERSA borrows on the foreign bond market and it changes the supply of domestic money by means of the exchange-rate stabilization operations. The market-clearing conditions for the domestic money market and the foreign bond market read in the present regime:

$$
\begin{gathered}
M_{H t}+M_{H t}^{*}=M_{H}+\sum_{\tau=1}^{t}\left(X_{H \tau}+X_{H \tau}^{E}\right), \quad t=1,2, \ldots, T, \\
B_{F t}+B_{F t}^{*}+B_{F t}^{E}=0, \quad t=1,2, \ldots, T .
\end{gathered}
$$

First let me prove that the one-sided peg fixed exchange-rate regime equilibrium allocation of consumption is the same as that in a barter economy. For this purpose recall the formulation of the optimal consumption plans that was developed at the end of Section III, and let us use formulations (12) and (13) for present purposes. It is sufficient to show that in the home country's problem (12), the righthand side of the wealth constraint equals the present value of output in equilibrium.

In a fixed exchange-rate regime the interest rate parity condition (3) reads $i_{H t}=i_{F t}=i_{t}, t=1,2, \ldots, T$, which implies equality of discount factors; that is, $d_{H t}=d_{F t}=d_{t}, t=1,2, \ldots, T$. Hence, the equality between the right-hand side of the wealth constraint in (12) and the present value of output translates in the present context into:

$$
M_{H}+\sum_{t=1}^{T-1} d_{t+1} p_{H t} y_{H t}+\sum_{t=1}^{T} d_{t} X_{H t}=\sum_{t=1}^{T} d_{t} p_{H t} y_{H t}
$$

which is equivalent to

$$
\sum_{t=1}^{T-1}\left(d_{t+1}-d_{t}\right) p_{H t} y_{H t}-d_{T} p_{H T} y_{H T}=-M_{H}-\sum_{t=1}^{T} d_{t} X_{H t} .
$$

Now if $i_{t}>0$ (i.e., $d_{t+1}<d_{t}$ ), money is not used as a store of value and all home money is spent on home goods, implying:

$$
\left(d_{t+1}-d_{t}\right) p_{H t} y_{H t}=\left(d_{t+1}-d_{t}\right)\left[M_{H}+\sum_{\tau=1}^{t}\left(X_{H \tau}+X_{H \tau}^{E}\right)\right] .
$$

If $i_{t}=0$ (i.e., $d_{t+1}=d_{t}$ ), then (24) holds trivially. Hence, (24) holds for $t=1,2, \ldots, T-1$. In the last period all money is spent on goods; therefore $p_{H T} y_{H T}=M_{H}+\Sigma_{\tau=1}^{T}\left(X_{H \tau}+X_{H \tau}^{E}\right)$. Combining the last result with (24) and applying the method employed in the Appendix, one gets: ${ }^{8}$

$$
\begin{gathered}
\sum_{t=1}^{T-1}\left(d_{t+1}-d_{t}\right) p_{H t} y_{H t}-d_{T} p_{H T} y_{H T}= \\
-M_{H}-\sum_{t=1}^{T} d_{H t}\left(X_{H t}+X_{H t}^{E}\right) .
\end{gathered}
$$

${ }^{8}$ For details see Helpman (1979). 
By comparing the last result with (23) it is clear that in order to prove (23) it remains to show that $\Sigma_{t=1}^{T} d_{H t} X_{H t}^{E}=0$. From (17) and (18), using the interest rate parity condition $i_{H t}=i_{F t}=i_{t}$, we have:

$$
X_{H t}^{E}=e\left[\left(1+i_{t-1}\right) B_{F t-1}^{E}-B_{F t}^{E}\right] .
$$

Hence, using the convention $B_{F 0}^{E}=0$ and the fact that $d_{t}\left(1+i_{t-1}\right)=$ $d_{t-1}$, we calculate

$$
\begin{aligned}
\sum_{t=1}^{T} d_{t} X_{H t}^{E} & =e \sum_{t=1}^{T} d_{t}\left[\left(1+i_{t-1}\right) B_{F t-1}^{E}-B_{F t}^{E}\right] \\
& =e\left(\sum_{t=2}^{T} d_{t-1} B_{F t-1}^{E}-\sum_{t=1}^{T} d_{t} B_{F t}^{E}\right)=-e d_{T} B_{F T}^{E}=0,
\end{aligned}
$$

which completes the proof (the last equality results from [20]).

I have shown that the equilibrium allocation of consumption in the present exchange-rate regime is the same as in a costless barter economy and, therefore, also the same as in an equilibrium of a floating exchange-rate regime. This means that the welfare level achieved by each country is the same in each (equilibrium) of these three alternative modes of organization of the world economy. What I wish to argue now is that the country that chooses to stabilize the exchange rate in the one-sided peg fixed exchange-rate regime cannot pursue an independent monetary (transfer) policy. In particular, for given transfer policies in the two countries, there is exactly one level at which it can stabilize the exchange rate and end up with no foreign debt. Put differently, if the country chooses to stabilize the exchange rate at a particular level, the requirement that it ends up with no foreign debt imposes on it a particular transfer policy; the present value of its transfers is uniquely determined, although their distribution over time can be freely chosen. Changes in the pattern of transfers change the pattern of deficits in the balance of payments but not the equilibrium pattern of consumption, provided the present value of transfers is maintained at the equilibrium level.

In order to prove my arguments, observe that the purchasing power parity condition $p_{H t}=e p_{F t}$ and (23) imply:

$$
M_{H}+\sum_{t=1}^{T} d_{t} X_{H t}=e\left[d_{T} p_{F T} y_{H T}+\sum_{t=1}^{T-1}\left(d_{t}-d_{t+1}\right) p_{F t} y_{H t}\right] .
$$

Since in the last period foreign money is spent on foreign goods,

$$
p_{F T}=\frac{\left(M_{F}+\sum_{t=1}^{T} X_{F t}\right)}{y_{F T}} .
$$


If $i_{t}>0, t \in\{1,2, \ldots, T-1\}$, then in period $t$ all foreign money is spent on foreign goods. If $i_{t}=0$, then $d_{t}=d_{t+1}$. Therefore,

$\left(d_{t}-d_{t+1}\right) p_{F t}=\left(d_{t}-d_{t+1}\right) \frac{\left(M_{F}+\sum_{\tau=1}^{t} X_{F \tau}\right)}{y_{F \tau}}, \quad t=1,2, \ldots, T-1$.

In addition,

$$
\frac{d_{t} p_{F t}}{d_{t-1} p_{F t-1}}=\frac{q_{t}}{q_{t-1}}, \quad t=2,3, \ldots, T, q_{1}=1,
$$

where $q_{t}$ is the equilibrium marginal rate of substitution between consumption in period $t$ and consumption in period 1. From (26) foreign prices and the discount factors are uniquely determined. They are, in fact, identical to the equilibrium foreign prices and foreign discount factors in a floating exchange-rate regime because the equilibrium marginal rates of substitution $q_{t}$ are the same in both regimes. Hence, the equilibrium value of the expression in the brackets on the right-hand side of (25) — which is positive - is independent of the home country's transfer policy and exchange-rate level. Therefore (25) implies a one-to-one relationship between the exchange-rate level and the present value of home money transfers.

\section{Fixed Exchange-Rate Regime: Cooperative Peg}

The last exchange-rate regime that I wish to consider is one in which both countries cooperate in the stabilization of the exchange rate. For this purpose the countries establish an ERSA which buys and sells currencies at a fixed rate of exchange, $e$ units of home currency per unit of foreign currency. The cooperation consists of each country's supplying the ERSA with its own currency whenever the ERSA is asked to sell it and is short on it. The ERSA does not engage in borrowing and lending. When foreign currency is sold to the ERSA, this transaction reduces the quantity of foreign currency in circulation. It also increases the quantity of home currency in circulation, with the increase equal in value to the reduced amount of foreign currency in circulation, since sales of foreign currency mean purchases of home currency. The opposite effect occurs when home currency is sold to the ERSA. This means that the operations of the ERSA do not change the aggregate value of monies in circulation; they only change their composition. However, transfer policies affect the aggregate quantity of money in circulation. The present regime is in line with recent modelings of fixed exchange-rate regimes in that 
the stabilization of the exchange rate per se does not affect the aggregate supply of money in the world economy. ${ }^{9}$

In the cooperative fixed exchange-rate regime the changes in money supply caused by the ERSA are (using the interest parity condition and the convention that variables with subscripts $t-1$ are zero for $t=1$ ):

$$
\begin{aligned}
X_{F T}^{E}= & {\left[M_{F t}+\left(1+i_{t-1}\right) B_{F t-1}-m_{F t-1}-B_{F t}\right] } \\
& -\frac{\left[M_{H t}^{*}+\left(1+i_{t-1}\right) B_{H t-1}^{*}-m_{H t-1}^{*}-B_{H t}^{*}\right]}{e}, \\
X_{H t}^{E}= & {\left[M_{H t}^{*}+\left(1+i_{t-1}\right) B_{H t-1}^{*}-m_{H t-1}^{*}-B_{H t}^{*}\right] } \\
& -e\left[M_{F t}+\left(1+i_{t-1}\right) B_{F t-1}-m_{F t-1}-B_{F t}\right] .
\end{aligned}
$$

Thus,

$$
X_{H t}^{E}+e X_{F t}^{E}=0, \quad t=1,2, \ldots, T .
$$

The definition of an equilibrium should by now be obvious and I abstain from stating it.

Using the equilibrium and parity conditions, one derives-by means of the method employed in the previous section-the following budget constraints on consumption vectors:

$$
\begin{gathered}
\sum_{t=1}^{T} d_{t} p_{H t} c_{t}=\sum_{t=1}^{T} d_{t} p_{H t} y_{H t}-\sum_{t=1}^{T} d_{t} X_{H t}^{E}, \\
\sum_{t=1}^{T} d_{t} p_{H t} c_{t}^{*}=\sum_{t=1}^{T} d_{t} p_{H t} y_{F t}-e \sum_{t=1}^{T} d_{t} X_{F t}^{E} .
\end{gathered}
$$

Due to (29), (30) implies that the equilibrium allocation of consumption in the cooperative fixed exchange-rate regime coincides with the equilibrium allocation of consumption in a barter economy if and only if the present value of monetary injections of currency $H$ (or contractions of currency $F$ ) caused by the operations of the ERSA is zero; that is, $\Sigma_{t=1}^{T} d_{t} X_{H t}^{E}=0$. I have shown in the previous section that in the one-sided fixed exchange-rate regime $\Sigma_{t=1}^{T} d_{t} X_{H t}^{E}$ is necessarily zero in an equilibrium. Here this is not the case; in an equilibrium of the present regime the present value of home currency injections

${ }^{9}$ If in a cooperative peg only one country sterilizes changes in its money supply that result from balance-of-payments adjustments, then the behavior of money supplies in this regime will resemble the behavior of money supplies in a one-sided peg regime. It is interesting to note that the prediction of the one-sided peg regime about the behavior of the world price level is consistent with the empirical findings in Genberg and Swoboda (1977) (i.e., that the money supply of the passive country, the United States, explains the world's dollar price level). Since they took the standard view of a fixed exchange rate (i.e., a cooperative peg), they explained their findings with an argument about sterilization on the part of the United States, an argument that they did not test. 
through the balance of payments need not be zero. ${ }^{10}$ If it is positive, the home country's present value of consumption is less than the present value of its output, and the foreign country's present value of consumption exceeds its present value of output. If it is negative, the opposite holds. In the former case it is as if the home country is making a transfer to the foreign country, while in the latter case it is as if the foreign country is making a transfer to the home country. Since in either case the allocation is efficient, then-to the extent that the transferer loses in welfare terms (which is not always the case)-in the former case the home country is worse off and the foreign country better off than in a floating exchange-rate regime (or a one-sided peg), while in the latter case the opposite holds. Since the outcome depends on the level of the exchange rate and on each country's transfer policy, countries have conflicting interests in the determination of the exchange-rate level and monetary policies.

\section{Concluding Remarks}

I have presented in this study an evaluation of exchange-rate regimes for a world economy in which there exists a single friction; that is, there exists a payments period and monies are required for market transactions. It has been shown that this friction has certain distributional implications in each exchange-rate regime, but it does not introduce inefficiencies into the economic system. All results are easily extended to a many-country framework. In a way, these results provide a benchmark for the evaluation of more realistic models and their implications about exchange-rate regimes.

There are various rigidities and imperfections (e.g., wage contracts, market imperfection) whose existence may have a bearing on the relative desirability of alternative exchange-rate regimes. Thus, it is possible that a particular exchange-rate regime performs better than others under certain types of imperfections. A characterization of imperfections under which each exchange-rate regime performs best will be valuable. Some work on the effects of uncertainty and imperfect capital markets is reported in Helpman and Razin (1980) and Lucas (1980b). Lucas provides conditions under which a floating exchange-rate regime is equivalent (from the allocational viewpoint) to a fixed exchange-rate regime, despite the existence of uncertainty and incomplete capital markets, while Helpman and Razin provide conditions under which a floating exchange-rate regime performs better than a one-sided peg.

There is also another aspect of exchange-rate regimes which has

${ }^{10}$ An example showing this point is presented in Helpman (1979). 
received no attention in a welfare context but which is of major importance, and this is the strategic behavior of governments. I have shown that the equilibrium allocation of consumption is efficient in every exchange-rate regime and that, in a floating exchange-rate regime as well as in a one-sided peg regime, it corresponds to the equilibrium allocation of consumption in a barter economy. A crucial assumption on which these results are based is that expectations are self-fulfilling; that is, there are no surprises. In particular, the transfer policies are announced at the very beginning, and each government honors its declared policy. What happens if in the course of time one of the governments deviates from its announced policy? This type of surprise destroys both results. This can be seen as follows. Suppose that at some point in time the foreign country is a net creditor in terms of foreign currency and it has zero net debt in terms of home currency. Then, by reducing the quantity of foreign money it increases via exchange-rate changes the real value of payments that it will receive for its outstanding credit. ${ }^{11}$ Thus, governments have an incentive to generate monetary surprises. But if they do it, one cannot analyze the consumer problem the way it was done in this paper, because the consumer will learn about the possible surprises and will accordingly adjust his decisions. Other governments will also adjust their policy. Hence, a game-theoretic framework, with an appropriate reformulation of individual problems, is required in order to analyze these issues properly.

The incentive for strategic behavior is even more apparent in the cooperative-peg regime. Recall that in this regime the exchange-rate level and the preannounced monetary policies determine real transfers among countries. There are, therefore, conflicting interests in the choice of an exchange-rate level and monetary (transfer) policies. In particular, once an exchange-rate level has been chosen, then in the course of time countries may try to secure for themselves higher welfare levels by departing from the preannounced monetary policies. Such unexpected departures generate allocational inefficiencies. Again, in order to analyze this problem properly, one needs an appropriate game-theoretic framework.

The need for an extension of the present analysis in order to take account of strategic behavior is clear from the context of this paper. However, such an analysis may also help to explain changes in exchange-rate regimes that took place in the world economy, such as the collapse of the Bretton Woods system.

\footnotetext{
11 A numerical example showing this effect is presented in Helpman (1979). Similar effects exist in the one-sided peg regime.
} 


\section{Appendix}

Here I prove that in a floating exchange-rate regime equilibrium the righthand side of the wealth constraint in (12) equals $\Sigma_{t=1}^{T} d_{H t} p_{H t} y_{H t}$. A similar method can be used to show that the right-hand side of the wealth constraint in (13) equals $\Sigma_{t=1}^{T} d_{F t} p_{F t} y_{F t}$. The proof proceeds as follows:

$$
\begin{gathered}
M_{H}+\sum_{t=1}^{T-1} d_{H t+1} p_{H t} y_{H t}+\sum_{t=1}^{T} d_{H t} X_{H t}=\sum_{t=1}^{T} d_{H t} p_{H t} y_{H t}+\left(M_{H}+\sum_{t=1}^{T} d_{H t} X_{t}\right) \\
+\sum_{t=1}^{T-1}\left(d_{H t+1}-d_{H t}\right) p_{H t} y_{H t}-d_{H T} p_{H T} y_{H T} .
\end{gathered}
$$

However, I have shown in Section III that for $i_{H t}>0\left(\right.$ or $\left.d_{H t+1}<d_{H t}\right)$ no one uses domestic money as a store of value, and that in the last period all money is spent. These results, together with the equilibrium conditions $b$ and $d$ in the definition of a floating exchange-rate regime equilibrium, imply

$$
\begin{gathered}
\left(d_{H t+1}-d_{H t}\right) p_{H t} y_{H t}=\left(d_{H t+1}-d_{H t}\right)\left(M_{H}+\sum_{\tau=1}^{t} X_{H \tau}\right), t=1,2, \ldots, T-1, \\
p_{H T} y_{H T}=M_{H}+\sum_{\tau=1}^{T} X_{H \tau} .
\end{gathered}
$$

This is so, since when domestic money is not used as a store of value in period $t$, all of it is spent on goods, implying $p_{H t} \tilde{c}_{H t}=\tilde{M}_{H t}$ and $p_{H t} \tilde{c}_{H t}^{*}=\tilde{M}_{H t}$. Using condition $b$ this implies that $p_{H t} y_{H t}=\tilde{M}_{H t}+\tilde{M}_{H t}^{*}$, which yields $p_{H t} y_{H t}=M_{H}+$ $\sum_{\tau=1}^{t} X_{H \tau}$ when combined with $d$. Thus, the above relations hold for $i_{H t}>0$, but they hold also trivially for $i_{H t}=0$ since $i_{H t}=0$ if and only if $d_{H t+1}=d_{H t}$. Using these results, we obtain:

$$
\begin{gathered}
\sum_{t=1}^{T-1}\left(d_{H t+1}-d_{H t}\right) p_{H t} y_{H t}-d_{H T} p_{H T} y_{H T}=\sum_{t=1}^{T-1}\left(d_{H t+1}-d_{H t}\right)\left(M_{H}+\sum_{\tau=1}^{t} X_{H \tau}\right) \\
-d_{H T}\left(M_{H}+\sum_{\tau=1}^{T} X_{H \tau}\right)=-M_{H}-\sum_{t=1}^{T} d_{H t} X_{H t} .
\end{gathered}
$$

The last equality is obtained from the fact that

$$
\sum_{t=1}^{T-1} d_{H t+1}-\sum_{t=1}^{T-1} d_{H t}-d_{H T}=\sum_{t=2}^{T-1} d_{H t}-\sum_{t=1}^{T-1} d_{H t}=-d_{H 1}=-1,
$$

and

$$
\begin{aligned}
& \sum_{t=1}^{T-1} d_{H t+1} \sum_{\tau=1}^{t} X_{H \tau}-\sum_{t=1}^{T-1} d_{H t} \sum_{\tau=1}^{t} X_{H \tau}-d_{H T} \sum_{\tau=1}^{T} X_{H \tau} \\
= & \sum_{t=1}^{T-2} d_{H t+1} \sum_{\tau=1}^{t} X_{H \tau}-X_{H 1}-\sum_{t=2}^{T-1} d_{H t} \sum_{\tau=1}^{t} X_{H \tau}-d_{H T} X_{H T}
\end{aligned}
$$




$$
=\sum_{t=2}^{T-1} d_{H t} \sum_{\tau=1}^{T-1} X_{H \tau}-\sum_{t=2}^{T-1} d_{H t} \sum_{\tau=1}^{t} X_{H \tau}-X_{H 1}-d_{H T} X_{H T}=-\sum_{t=1}^{T} d_{H t} X_{H t}
$$

Combining (A1) with (A2), we obtain

$$
M_{H}+\sum_{t=1}^{T-1} d_{H t+1} p_{H t} y_{H t}+\sum_{t=1}^{T} d_{H t} X_{H t}=\sum_{t=1}^{T} d_{H t} p_{H t} y_{H t} .
$$

This completes the proof for the home country. A similar proof applies to the foreign country.

\section{References}

Baumol, William J. "The Transactions Demand for Cash: An Inventory Theoretic Approach.” Q.J.E. 66 (November 1952): 545-56.

Clower, Robert W. "A Reconsideration of the Microfoundations of Monetary Theory." Western Econ. J. 6 (December 1967): 1-8.

Flanders, M. June, and Helpman, Elhanan. "On Exchange Rate Policies for a Small Country." Econ. J. 88 (March 1978): 44-58.

Friedman, Milton. "The Case for Flexible Exchange Rates." In Essays in Positive Economics. Chicago: Univ. Chicago Press, 1953.

Genberg, Hans, and Swoboda, Alexander K. "Worldwide Inflation under the Dollar Standard." Discussion Paper no. 12, Grad. Inst. Internat. Studies, Geneva. Revised version, January 1977.

Helpman, Elhanan. "An Exploration in the Theory of Exchange Rate Regimes.” Working Paper no. 79-2, Univ. Rochester, Dept. Econ., January 1979.

Helpman, Elhanan, and Razin, Assaf. "Towards a Consistent Comparison of Alternative Exchange Rate Systems." Canadian J. Econ. 12 (August 1979): 394-409.

- "A Comparison of Exchange Rate Regimes in the Presence of Imperfect Capital Markets.” Seminar Paper no. 156, Univ. Stockholm, Inst. Internat. Econ. Studies, October 1980.

. "Dynamics of a Floating Exchange Rate Regime." Working Paper no. 21-81, Tel-Aviv Univ., Foerder Inst. Econ. Res., May 1981.

Hicks, John R. "The Two Triads." Lectures 1 and 2 in Critical Essays in Monetary Theory. Oxford: Clarendon, 1967.

Kareken, John H., and Wallace, Neil. "Samuelson's Consumption-Loan Model with Country Specific Fiat Monies." Q.J.E. (in press).

Lucas, Robert E., Jr. "Equilibrium in a Pure Currency Economy." Econ. Inquiry 18 (April 1980): 203-20. (a)

- "Notes on the Efficiency of Exchange Rate Regimes." Private notes, March 1980. (b)

Mundell, Robert A. International Economics. New York: Macmillan, 1968.

Stockman, Alan C. "A Theory of Exchange Rate Determination." J.P.E. 88, no. 4 (August 1980): 673-98.

Tobin, James. "The Interest-Elasticity of Transactions Demand for Cash." Rev. Econ. and Statis. 38 (August 1956): 241-47. 